Article

\title{
The Role of Intermediation in the Governance of Sustainable Chinese Web Marketing
}

\section{Yongrok Choi * and Di Gao}

Department of International Trade and Regional Studies, Inha University, 100 Inha-ro, Nam-gu, Incheon 402-751, Korea

* Author to whom correspondence should be addressed; E-Mail: yrchoi@inha.ac.kr; Tel.: +86-791-8381-0553; Fax: +86-791-8381-0892.

Received: 16 June 2014; in revised form: 21 June 2014 / Accepted: 23 June 2014 /

Published: 30 June 2014

\begin{abstract}
This paper identifies the factors necessary for the sustainable performance of two Chinese web marketing companies. The companies are Alibaba and its twin, Taobao. This research is based on the structural equation model (SEM). The paper analyzes the core governance factors of Chinese trust (Guanxi) from outperforming web marketing mix strategies to determine if Guanxi can be applied to other web community marketing strategies. The empirical tests, in general, show the web marketing mix is important to create values in China. Three other web marketing strategies - communication, content, and commerce incorporate Guanxi with full mediation effects. Some implications concerning trust enhancement by the Chinese government and web companies are suggested.
\end{abstract}

Keywords: web marketing mix (4Cs); Chinese trust (Guanxi); mediation effect; structural equation model (SEM); governance

\section{Introduction}

China represents one of the most rapidly changing countries in the world. China has been a fast follower with respect to economic development, particularly in the fields of information and communication technology (ICT) and e-business. Recently, the economy has re-oriented its traditional export brick industry paradigm towards the evolving IT industry. This dynamic has brought innovation to the Chinese IT and e-business industry fields improving the economy. The Chinese web companies have made efforts to connect Chinese worldwide "Huaqiao" with their ethnic and cultural background. 
Huaqiao is defined as the Chinese population abroad who have an ethnically-based tendency to prefer Chinese interpersonal relationships that are based on Chinese trust (Guanxi). Huaqiao was originally based on individual Guanxi relationships. However, the rapidly evolving internet and related e-business has enabled many Chinese Huaqiaos worldwide to connect quickly, and their loyalty has ensured the success of ICT and e-business organizations.

Since the Chinese market is huge, diverse and rapidly evolving, with a unique cultural background, global e-business companies such as eBay and Amazon.com should change their strategies to adapt or localize Chinese Guanxi for successful operation in the global Chinese market. Figure 1 shows that the number of Internet users in China rapidly increased to $45.8 \%$ in the year 2013. Moreover, internet shopping mall users represent $48.9 \%$ (or 0.3 billion) of all internet users [1]. If overseas users and buyers are included, the statistics are even greater.

Figure 1. Internet users and the penetration rate for China (Unit: 10 million, \%).

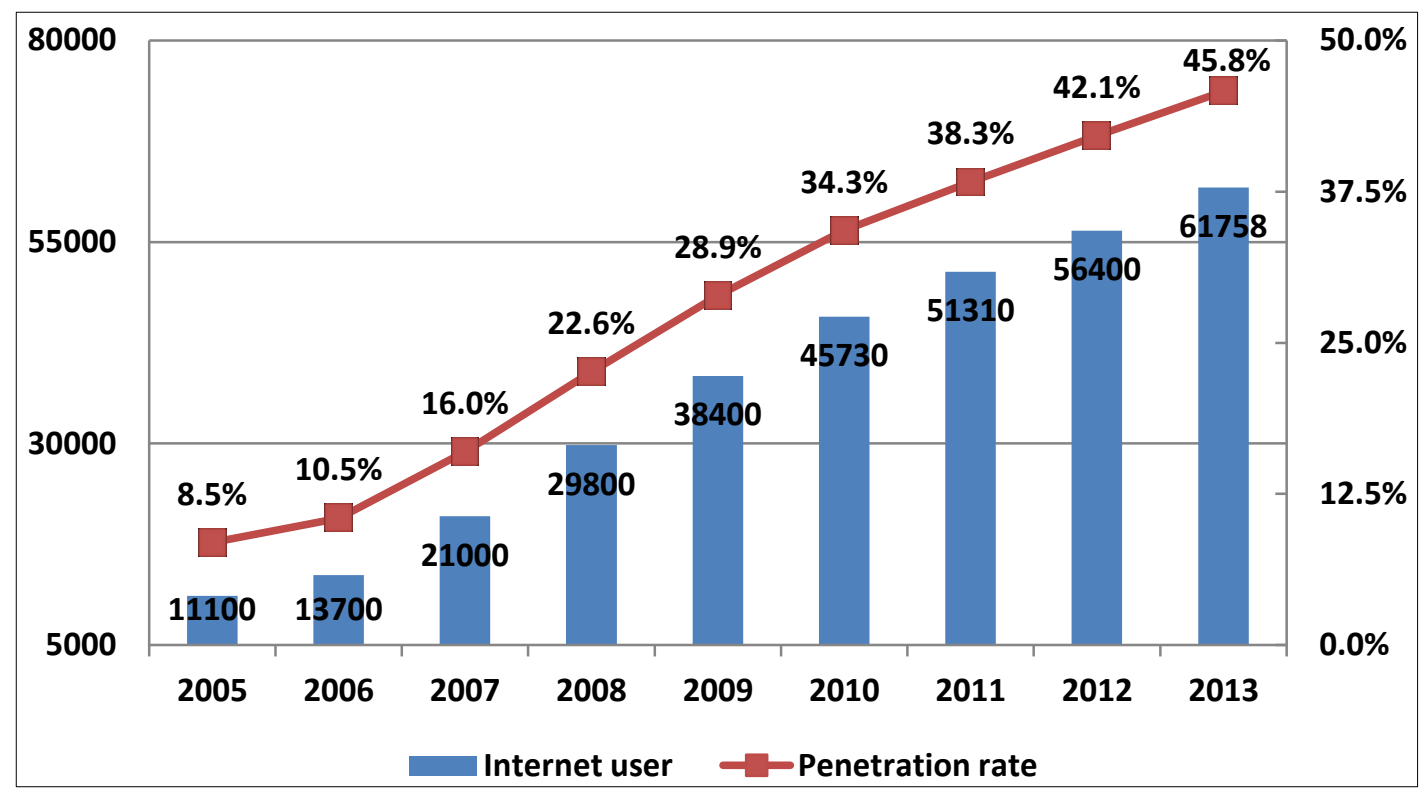

Source: Chinese Internet Network Information Center (CNNIC)

Alibaba Group is the most representatively successful web business in China. It is a private e-business group with business-to-business online web portals, online retail and payment services, a shopping search engine, and proprietary data-based cloud computing services. In 2012, the business portals of Alibaba and its twin web business of Taobao together achieved 1.1 trillion yuan ( $\$ 170$ billion) in sales, surpassing the global competitors, eBay and Amazon.com, combined [2]. The company began to connect Chinese manufacturers with overseas buyers, transforming off-line Huaqiaos worldwide into online customers. The consumer-to-consumer (C2C) portal Taobao, which is similar to eBay, features nearly a billion products and is one of the 20 most visited web sites globally. The Alibaba Group's sites account for over $60 \%$ of the parcels delivered in China [2]. The $\mathrm{C} 2 \mathrm{C}$ portal Taobao has gained popularity and claims $96.4 \%$ of the $\mathrm{C} 2 \mathrm{C}$ market as a result of viral marketing that is based on Chinese trust (Guanxi).

China is one of the largest countries in the world and, therefore, commerce can be beset with bottlenecks such as poor delivery systems, ineffective information security, weak infrastructure, and limited access to the Internet environment. The Chinese government imposes severe regulations on the 
internet and its users [3,4]. Nonetheless, the successful performance of Chinese web marketing companies may be a consequence of significant governance factors in web marketing strategy. This paper identifies the notable governance factors from a web marketing perspective. The remainder of this paper is organized as follows. Section 2 describes the conceptual characteristics of web marketing strategies and presents related hypotheses for web marketing strategies. Section 3 employs the methodology of the structural equation model (SEM) to empirically test the sustainable performance of Chinese web marketing companies. Section 4 concludes with some implications.

\section{The Web Marketing Mix and Its Model}

\subsection{Conceptual Characteristics of the Web Marketing Mix}

The rapid diffusion of e-business has revolutionized our daily lives. Although the traditional approaches of economics or business management remain popular, the "smart" use of the internet has changed the business and economic environment. The paradigm of traditional business management was to maximize profits, and it incorporated diverse marketing activities, particularly the strategic mix of the four marketing tools - product, price, place, and promotion. However, market leadership has transferred to the companies who integrate the consumer into the production process and cater to the "prosumer", who means the active consumers to participate in the production process. For these companies, the traditional push marketing model using the 4Ps is losing relevance. The leading products provide satisfaction, but the leading services provide an emotional relationship, which is the essence of pull marketing. Based on this pull marketing approach, the sustainable governance of marketing emphasizes relational management.

Web marketing is defined as relationship marketing that creates long-term network management value via collaboration and customization [5]. Web marketing is based on the creation of value from relationships among network members. There is a fundamental difference between web marketing and traditional marketing. Web marketers must reward customers for their loyalty with similar strategies as traditional marketers. Long-term success requires persistent loyalty as a core factor of web marketing. Customer loyalty enlarges future sales volume and exponentially increases sales through viral marketing. Relationship management is central to the creation of value for the network manager. Web marketing should emphasize relationship building, relationship management, and value creation from relationships. To identify the factors involved, the procedural structure of web marketing and its components with respect to the four Cs must be defined. Communications, contents, commerce, and community form the core of relational management. Because the Chinese commercial transaction is based on Chinese trust (Guanxi), this relational management factor is key with respect to governance for Chinese web marketers and their ability to outperform the Chinese and global markets.

Based on the procedural approach of web marketing, the first strategy that web marketers employ with respect to the new user is customer familiarization with the web site. Thus, communication is the starting point of the relationship. Once the new user feels comfortable with accessing and using the site, interest in frequent visits can be built, which is the basic strategy behind site contents. Frequent visits represent the core objective of web marketing, which is to create value based on commerce strategies. Users should sense a community that reflects the maxim "once a friend, forever a friend." 
The four strategies represent a step-by-step approach to create a relationship, maintain it, and utilize it for the creation of value. These strategies are interconnected and form a web marketing strategy matrix - the web marketing mix 4Cs.

\subsection{Literature Review}

The paradigm of the web marketing mix is to create value based on sustainable relationship management. The most significant characteristic of the sustainable relationship is loyalty. Substantial studies address customer loyalty, and the majority of previous literature emphasizes the intermediation of satisfaction for sustainable loyalty. This section addresses the basic theories and model with respect to the web marketing mix.

The paradigm of sustainable relationship building using the web marketing mix defines customer loyalty as faithfulness or devotion to a product, service, and/or the company. Loyalty could represent a consumer preference for a particular product (or brand) and a commitment to repeatedly purchase that brand despite other choices [6]. The majority of the literature differentiates between the perceived desire to buy that represents potential loyalty, and repeat purchase that represents behavioral loyalty [7-9]. The former emphasizes psychological factors such as organizational commitment, repurchase desire, and willingness to recommend the item to others, while the latter focuses on measurable levels of revealed preferences such as the repurchase ratio, the frequency of transactions, and the number of repurchases [9].

Customer loyalty is the outcome of effective company marketing activities, and it is also the case for web marketing companies in areas such as B2B, B2C or C2C. For example, to encourage customer loyalty, China's Tenmao of Alibaba and Taobao provided a quality guarantee that allowed the customer to return a product for any reason within seven days, and the repurchase value was returned as cash to spend on that same site at any time. This type of web marketing mix strategy provides customer loyalty through relationship management.

\subsection{Direct Model Web Marketing Mix Hypotheses}

Communication with respect to web marketing is defined as the activity of conveying information through the exchange of ideas, feelings, and attitudes by means of the internet. As the first step-wise approach to relationship management, communication is the initial catalyst in the web marketer and customer relationship. Effective communication should generate and sustain relationships.

To effectively communicate with new visitors, web marketers should eliminate the practical and psychological barriers that visitors might experience. For example, the Aribaba group developed a communication strategy with Ariwangwang, which is a one-to-one cyber troubleshooting platform to overcome practical barriers. Using this communication channel, new entrants can access necessary product information and related services. To address psychological barriers to effective access, web marketers should provide customized e-mails to web managers alerting them of reliability assurances and award records received from the public for exemplary service. To ensure practical and easy access to a web site, workable menus, real-time service updates, and a user-friendly web environment are necessary. Selnes [10] argued that loyalty is a consequence of a psychological barriers to transfer to other another option, or practical barriers such as high transfer costs. Therefore, the following communication hypothesis is proposed. 
- H1: Communication strategies positively impact concerning web user loyalty.

Internet users visit sites that provide real-time information such as exchange rates, weather, and news, and/or an interesting attraction such as a free game. All of these elements represent contents strategy. With respect to web marketing, content represents information and experiences that provide value for internet users in specific contexts [11]. The contents, therefore, can influence visit frequency. Frequent visits build familiarity with web sites that offer useful information and/or fun experiences. The customer becomes accustomed to the web sites, which maintains the relationship. Therefore, the following hypothesis with respect to content is proposed.

- H2: Contents strategies positively impact web user loyalty.

The third stage of the web marketing mix is based on commerce strategy. Frequent visits themselves only provide an illusion of sales. Therefore, the basic core strategies of web marketing are connected with the creation of commercial value. However, commercial value should be differentiated from the traditional direct sales profits because web marketing may use one-source multi-use with its own web sites and may create revenues from diverse source of values. The web manager may tolerate a lower price than the cost of production because there may be complementary compensation from advertising commissions and/or membership fees. In some cases, the loss of profit may be compensated by rent from other web site residents and/or a consulting premium for offline activities. Therefore, diverse revenue sources with the same product or services are feasible in addition to traditional profits. Ahn lab, a leading Korean antivaccine company, obtains profits from membership fees, whereas another anti-vaccine company with free membership, Alyak, obtains value from advertising commission during on-line vaccine checking and updating. China's Tenmao uses diverse commerce strategies, such as new movie advertising commissions and rent for other small website retailers on the Tenmao web sites. Such diverse commerce strategies are based on customer loyalty, which in itself represents a diverse source of commerce [12]. Therefore, the following hypothesis with respect to commerce is proposed.

- H3: Commerce strategies positively impact web user loyalty.

Web marketing follows the maxim "once a customer, forever a customer." Therefore, the postpurchase services provided to buyers are significant. For example, Tenmao of Alibaba created the Tenmao forum on which frequent visitors share ideas. This platform has become a social network where a loyal community engages in word-of-mouth marketing. An empirical test on the performance of the Taiwanese educational system concluded that managerial commitment and systems oriented toward the community are integral to organizational loyalty [13]. Based on these arguments, the following hypothesis concerning communication is proposed.

- H4: Community strategies positively impact web user loyalty.

All of the web marketing hypotheses are based on loyalty because value creation from relational loyalty is the goal of web marketing, not profit maximization. The successful performance of Chinese web marketing companies can be represented by the direct model in Figure 2. 
Figure 2. Direct model: The web marketing mix and hypotheses.

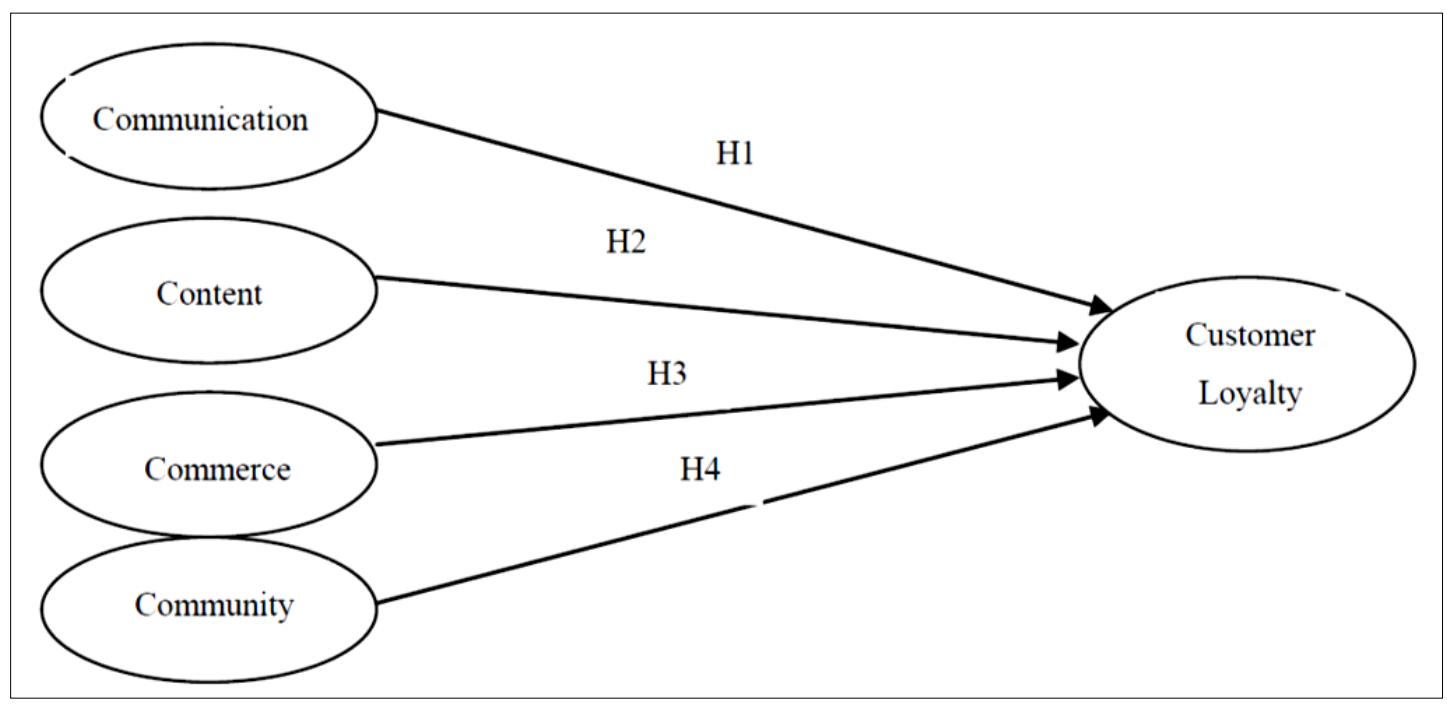

\subsection{Indirect Model with Intermediation}

Despite the significance of customer loyalty, particularly Chinese trust (Guanxi), some of the literature concludes that loyalty is not necessarily a central factor in the web marketing mix. The lack of consensus concerning loyalty may originate from a culture of pragmatism among the Chinese people because of continuous wars and severe poverty that have plagued the nation's history. The word "Shengyi" in China refers to the business characteristics of a person, not the life purpose of an individual [14]. Salesmanship is a born-in-characteristic in China; thus, loyalty may not be the direct result of web marketing. A website may possess no customer loyalty, but the traffic on the site from information seekers may result in a commercial transaction. This dynamic represents a missing link between loyalty and web marketing performance.

The majority of literature concerning trust and loyalty emphasize the governance factor of customer satisfaction, even with respect to the web marketing mix [15-18]. Customer satisfaction should affect customer loyalty, but not vice versa [18]. Kotler [16] defined satisfaction as an individual's sense of pleasure or disappointment resulting from a comparison of a product's perceived performance (or outcome) and expectations. According to Hansemark and Albinsson [17], satisfaction is an overall customer attitude towards a service provider, or an emotional reaction to the difference between the customer's anticipated fulfillment of some need, goal or desire and actual fulfillment. However, Oliver [18] summarizes the transaction-specific nature of satisfaction and differentiates it from attitude. The author states that the satisfaction is consumption-specific, whereas the attitude (or loyalty) comes from an enduring affective orientation for a product or service. From the consumer's perspective, satisfaction is a desirable end-state of consumption or patronization; it is a reinforcing pleasurable experience [19]. Satisfaction is provided by the product or service itself and may or may not result in loyalty. Chang [20] argued that loyalty may stem from repeat purchases, and satisfaction itself may not depend on loyalty.

All of these arguments imply a missing link between the web marketing mix and the goal of gaining customer loyalty. Therefore, an analysis of the intermediary variable of satisfaction can reveal the governance concerning the sustainable performance of the web marketing mix with respect to loyalty. To identify the missing link between loyalty and satisfaction concerning web marketing strategies, the 
hypotheses with respect to the intermediary variable of satisfaction represent the indirect model in Figure 3. The hypotheses consist of the following.

Figure 3. Indirect model with intermediation.

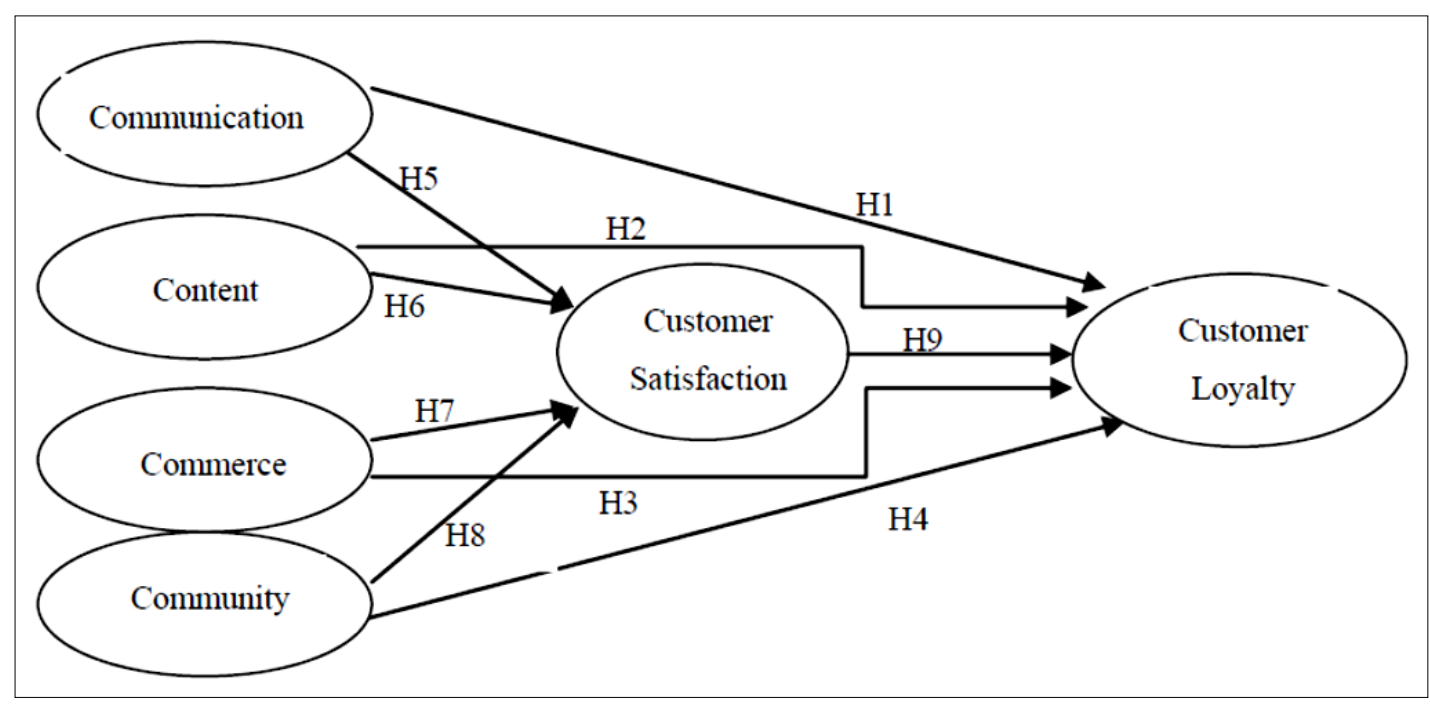

- H5: Communication strategies positively impact the consumer's satisfaction.

- H6: Content strategies positively impact consumer satisfaction.

- H7: Commerce strategies positively impact consumer satisfaction.

- H8: Community strategies positively impact consumer satisfaction.

- H9: Consumer satisfaction positively impacts consumer loyalty.

\section{Empirical Tests and Implications}

\subsection{Data and Methodology}

The data for the empirical tests were collected using a survey questionnaire. An initial pilot study was conducted. Fifty consumers with extensive online shopping experience were invited to complete the questionnaires. Based on the Cronbach alpha coefficients $(a>6)$, some items were modified. Additionally, Chinese web marketing experts were invited to complete the questionnaire as a pilot test. The questionnaire was then modified based on the expert feedback.

The questionnaire survey was administered during the period 16 January to 22 February 2014. A total of 350 questionnaires were sent randomly to Chinese online shoppers by e-mail or messenger. The shoppers were retrieved from business yellow pages for various sectors and provinces nationwide, only when they had an experience with Alibaba and/or Tabao web markets. A total of 153 unique and usable organizational responses were received (the response rate was 43.7\%). Table 1 presents the demographic characteristics of the respondents. They represent most of internet users in China with high portions on $20 \mathrm{~s}$ and $30 \mathrm{~s}(90.4 \%)$, and with university background (64.1\%). 
Table 1. Demographic characteristics.

\begin{tabular}{lcc}
\hline Characteristic & Frequency & Percent (\%) \\
\hline Gender & & \\
Male & 66 & 43.1 \\
Female & 87 & 56.9 \\
Education Level & & \\
High school & 36 & 23.5 \\
University & 98 & 64.1 \\
Graduate school & 19 & 12.4 \\
Age & & \\
$20-29$ & 64 & 41.8 \\
$30-39$ & 59 & 38.6 \\
$40-49$ & 30 & 19.6 \\
Income (per month, Chinese Yuan) & \\
$500-1000$ & 17 & 11.1 \\
$1000-2000$ & 53 & 34.6 \\
$2000-3000$ & 65 & 42.5 \\
3000 or over & 18 & 11.8 \\
\hline
\end{tabular}

We compared the early and late respondents to overcome the problem of non-response bias, as recommended by Armstrong and Overton [21]. The 175 questionnaires were divided into two groups based upon the time of completion. An independent $t$-test was employed to examine any differences between the early and late completion groups. The results indicated no significant differences in various items between these two groups, suggesting that our sample is free from non-response bias.

To measure all the observed variables in this study, we adopted existing well-established multiple-item, seven-point Likert scales. These scales ranged from 1 ("strongly disagree") to 7 ("strongly agree"). We chose seven-point Likert scales because some Chinese people do not want the extreme answers and thus it is difficult to handle with five-point Likert scales for some questions. The detailed measurement items are presented in Table A1. The communication strategies in the web marketing mix were analyzed using five categorical questions concerning the level of easy and effective access to the websites to evaluate the psychological and practical barriers to web site access. The contents strategies were analyzed using four questions designed to illicit insightful information concerning the overall design of website menus and the privacy or security level of the web content. The commerce strategies were analyzed using four questions concerning the quality of the product, price, promotion, and services. The final phase of web marketing strategies was analyzed using five community-related questions concerning the frequency of website participation. All of the questions were based on Taobao, the most representative e-shopping mall in China, and all the respondents possessed experience on this particular web site. Based on the two stepwise approaches, a reliability test was conducted followed by the structural empirical tests. 


\subsection{Reliability Test}

Our proposed model must be statistically reliable and valid. Reliability is used to describe the overall consistency of a measure. The proposed method should reflect similar results when tested again under the same conditions. For the reliability test, we used the widely known Cronbach's alpha coefficient, the corrected item total correlation coefficient, and the construct reliability coefficient. These represent the most commonly used criteria for measuring reliability. Table 2 shows that each measure is above the suggested threshold at $0.7,0.5$, and 0.8 and thus, these values are considered adequate to confirm a satisfactory level of reliability in this study.

Table 2. Reliability test of the latent variables.

\begin{tabular}{lcccc}
\hline Latent variables & No. of items & $\begin{array}{c}\text { Cronbach's } \\
\text { alpha }(>\mathbf{0 . 7})\end{array}$ & $\begin{array}{c}\text { Corrected item-total } \\
\text { correlation }(>\mathbf{0 . 5})\end{array}$ & $\begin{array}{c}\text { Construct } \\
\text { reliability }(>\mathbf{0 . 8})\end{array}$ \\
\hline Communication & 5 & 0.828 & $0.595-0.656$ & 0.829 \\
Content & 4 & 0.796 & $0.551-0.636$ & 0.796 \\
Commerce & 4 & 0.850 & $0.619-0.741$ & 0.852 \\
Community & 5 & 0.910 & $0.736-0.818$ & 0.910 \\
Customer satisfaction & 4 & 0.858 & $0.683-0.731$ & 0.859 \\
Customer loyalty & 5 & 0.867 & $0.627-0.741$ & 0.867 \\
\hline
\end{tabular}

\subsection{Validity Test}

The validity of an assessment is the extent to which the target is accurately measured (the true information). The validity analysis includes both content validity and construct validity components. The content validity analysis tests the representativeness of the items in the questionnaire. We found no reports of any misunderstanding during the pilot test. The interviewees stated that the items were easily understood, which indicates content validity [22].

The confirmatory factor analysis (CFA) is an effective tool used to test construct validity. According to Campbell and Fiske [23], construct validity research typically tests the extent to which data provides (a) convergent validity - this is the extent to which different assessment methods show similar measurements of the same trait (i.e., construct; ideally, these values should be moderately high), and (b) discriminant validity. Discriminant validity is the extent to which independent assessment methods show divergent measurements of different traits (ideally, these values should demonstrate minimal convergence).

As summarized by Choi and Yu [24], convergent validity occurs when (a) all factor loadings are significantly over the 0.5 cut-off point and, (b) the average variance extracted (AVE) from items by their respective constructs is greater than 0.5 . Table 3 shows the results of the convergent validity measured using CFA. We recognize that the measurement scale shows a strong convergent validity because all of the factor loadings are significant and over 0.5, and the AVE of all the items is larger than 0.5 . 
Table 3. Convergent validity test on the measurement model.

\begin{tabular}{|c|c|c|c|}
\hline Variable & SFL $^{\mathrm{a}}$ & C. $\mathbf{R}^{\mathbf{b}}$ & $\mathbf{A V E}^{\mathrm{c}}$ \\
\hline Communication strategies & & & 0.615 \\
\hline Com1-Easy access in general & 0.657 & 7.870 & \\
\hline Com2-Easy access by Aliwangwang & 0.577 & 7.402 & \\
\hline Com3-Reply speed & 0.685 & 7.764 & \\
\hline Com4-Effective access to information & 0.555 & 7.381 & \\
\hline Com5-Credibility on access & 0.600 & - & \\
\hline Content strategies & & & 0.638 \\
\hline Con1-Design attractiveness & 0.646 & 6.669 & \\
\hline Con2-Relevant content & 0.662 & 6.653 & \\
\hline Con3-Accurate content & 0.625 & 6.311 & \\
\hline Con4-Privacy concerning content & 0.617 & - & \\
\hline Commerce strategies & & & 0.706 \\
\hline Cmc1-Price competitiveness & 0.724 & 7.882 & \\
\hline Cmc2-Advertisement usefulness & 0.751 & 8.428 & \\
\hline Cmc3-Events and activities & 0.739 & 8.540 & \\
\hline Cmc4-Coupon and promotion & 0.600 & - & \\
\hline Community strategies & & & 0.765 \\
\hline Cot1-Friendliness & 0.687 & 10.507 & \\
\hline Cot2-Percieved acceptance & 0.697 & 10.765 & \\
\hline Cot3-Knowledge of the community & 0.822 & 12.357 & \\
\hline Cot4-Participation level of the community & 0.808 & 12.006 & \\
\hline Cot5-Pro-active level of the community & 0.755 & - & \\
\hline Customer satisfaction (CS) & & & 0.710 \\
\hline Sat1-Perceived satisfaction with purchase & 0.657 & - & \\
\hline Sat2-Satisfaction with web service & 0.679 & 7.585 & \\
\hline Sat3-Satisfaction with price & 0.743 & 7.957 & \\
\hline Sat4-Perceived evaluation of shopping experience & 0.760 & 8.265 & \\
\hline Customer loyalty & & & 0.659 \\
\hline Loy1-Visit frequency & 0.728 & - & \\
\hline Loy2-Memory of the attraction & 0.644 & 8.571 & \\
\hline Loy3-Recommendation level & 0.721 & 9.309 & \\
\hline $\begin{array}{l}\text { Loy3-Recommendation level } \\
\text { Loy4-Loyalty to the brand even with a higher price }\end{array}$ & 0.652 & 7.936 & \\
\hline Loy5-Intention to purchase volume & 0.564 & 7.404 & \\
\hline \multicolumn{4}{|c|}{$\begin{array}{l}\text { Goodness-of-fit and recommended cut-off point } \\
\chi^{2}=289.8\left(\text { direct model; DM), } 405.551 \text { (indirect model; IM); } \chi^{2} / d f(<5)=1.32(\mathrm{DM}),\right. \\
1.31(\mathrm{IM}) ; \mathrm{CFI}(>0.9)=0.959(\mathrm{DM}), 0.954(\mathrm{IM}) ; \mathrm{RMSEA}(<0.1)=0.046(\mathrm{DM}), 0,045(\mathrm{IM})\end{array}$} \\
\hline
\end{tabular}

For the model fit of CFA, we also used a number of goodness-of-fit indices recommended in previous studies such as a normed chi-square $\left(\chi^{2} / \mathrm{df}\right)$, goodness-of-fit (GFI), comparative fit index (CFI), root mean square residual (RMR), and root mean square error of approximation (RMSEA) [25]. 
We find in our measurement model that all of the various overall goodness-of-fit measures are superior to the recommended criteria. Thus, the construct validity of the measurement model is acceptable.

With respect to discriminant validity, the square root of the AVE for the constructs should be larger than any respective inter-construct correlations. Table 4 shows that the square roots of the AVE of all the variables are higher than their inter-correlations, which supports the discriminant validity.

Table 4. Discriminant validity test of the measurement model.

\begin{tabular}{lllllll}
\hline Construct items & Communication & Contents & Commerce & Community & CS & Loyalty \\
\hline Communication & $0.765^{\mathrm{a}}$ & & & & & \\
Contents & 0.466 & $0.706^{\mathrm{a}}$ & & & & \\
Commerce & 0.448 & 0.417 & $0.638^{\mathrm{a}}$ & & & \\
Community & 0.427 & 0.299 & 0.544 & $0.615^{\mathrm{a}}$ & & \\
CS & 0.591 & 0.478 & 0.545 & 0.534 & $0.710^{\mathrm{a}}$ & \\
Loyalty & 0.545 & 0.466 & 0.528 & 0.500 & 0.659 & $0.752^{\mathrm{a}}$ \\
\hline
\end{tabular}

a The square root of the AVE as a criteria of the cutting point for correlation. CS: Customer Satisfaction.

\subsection{Hypotheses Test}

Following the confirmation of the reliability and validity of the questionnaire, we also conducted the goodness of fit test for overall model fit. Table 3 shows that all the statistics for the direct model (DM) and the indirect model with intermediary (IM) are statistically significant as a whole, compared with the critical values of $\chi^{2} / d f(<5)$, CFI $(>0.9)$, RMSEA $(<0.10)$.

Based on these tests, we now test the proposed hypotheses. By using the SEM, we find that the ML estimation method fits our data most appropriately; therefore, ML estimation is used for the hypotheses testing. The empirical findings are presented in Figure 4. Our results show that all the web marketing strategies have a positive impact on customer loyalty. Therefore, H1 to H4 are supported $(p<0.005)$. Among the web marketing mix strategies, communication is the most influential concerning customer loyalty, whereas the content contribution is the least influential.

To test the mediating effect of organizational commitment and citizenship behavior, the relationships among the variables should satisfy all of the following conditions as suggested by the references [24,26]: (1) the independent variable should significantly influence the dependent variable; (2) the independent variable should influence the mediator significantly; (3) the mediator must influence the dependent variable significantly, and (4) the impact of the independent variable on the dependent variable must diminish after controlling for the effects of the mediator. If any of these conditions are not satisfied, there is no mediation. If all of these conditions are satisfied and the influence of the independent variable becomes non-significant in the presence of the mediator, the effects of the independent variable are said to be completely or fully mediated by the mediator. If all the conditions are satisfied, while the influence of the independent variable remains significant in the presence of the mediator, the effects of the independent variable are said to be partially mediated [26-28]. 
Figure 4. The results of the direct model.

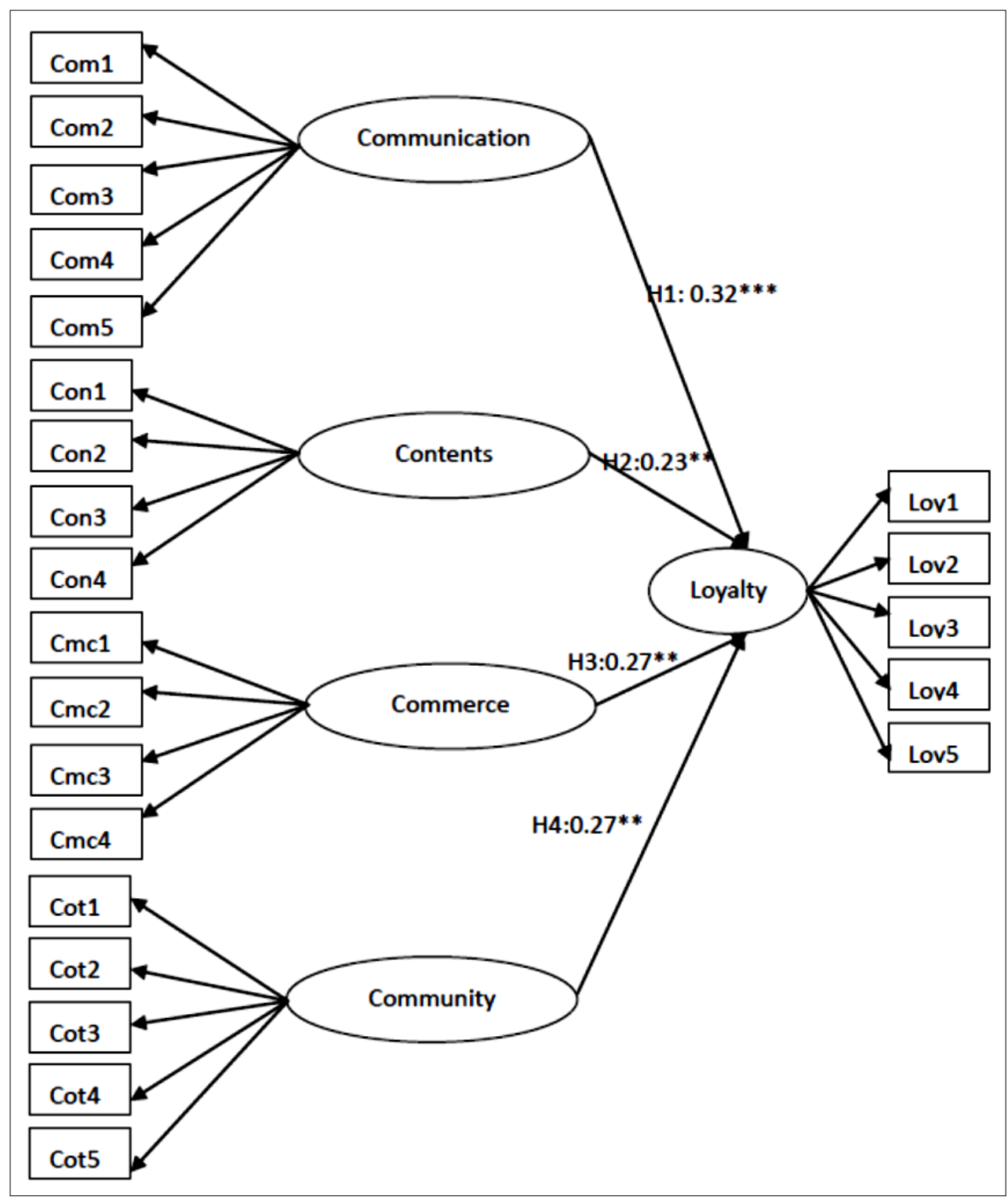

Compared with the direct model in Figure 4, the results of the mediation model in Figure 5 show that the mediatory hypotheses H5, H6, H7, and H8 support condition (1); hypotheses H1, H2, H3, and H4 support condition (2), and H9 supports condition (3). With respect to the mediator condition (4) concerning consumer satisfaction, communication, contents, and commerce have no effect on consumer satisfaction, whereas the effect of community has a lower but marginally significant effect $(p>0.01)$. Therefore, we conclude that the relationship between communication, content, and commerce strategies are fully mediated by customer satisfaction, whereas the community strategy of the web marketing mix is partially mediated by customer satisfaction concerning loyalty. 
Figure 5. The results of the indirect model.

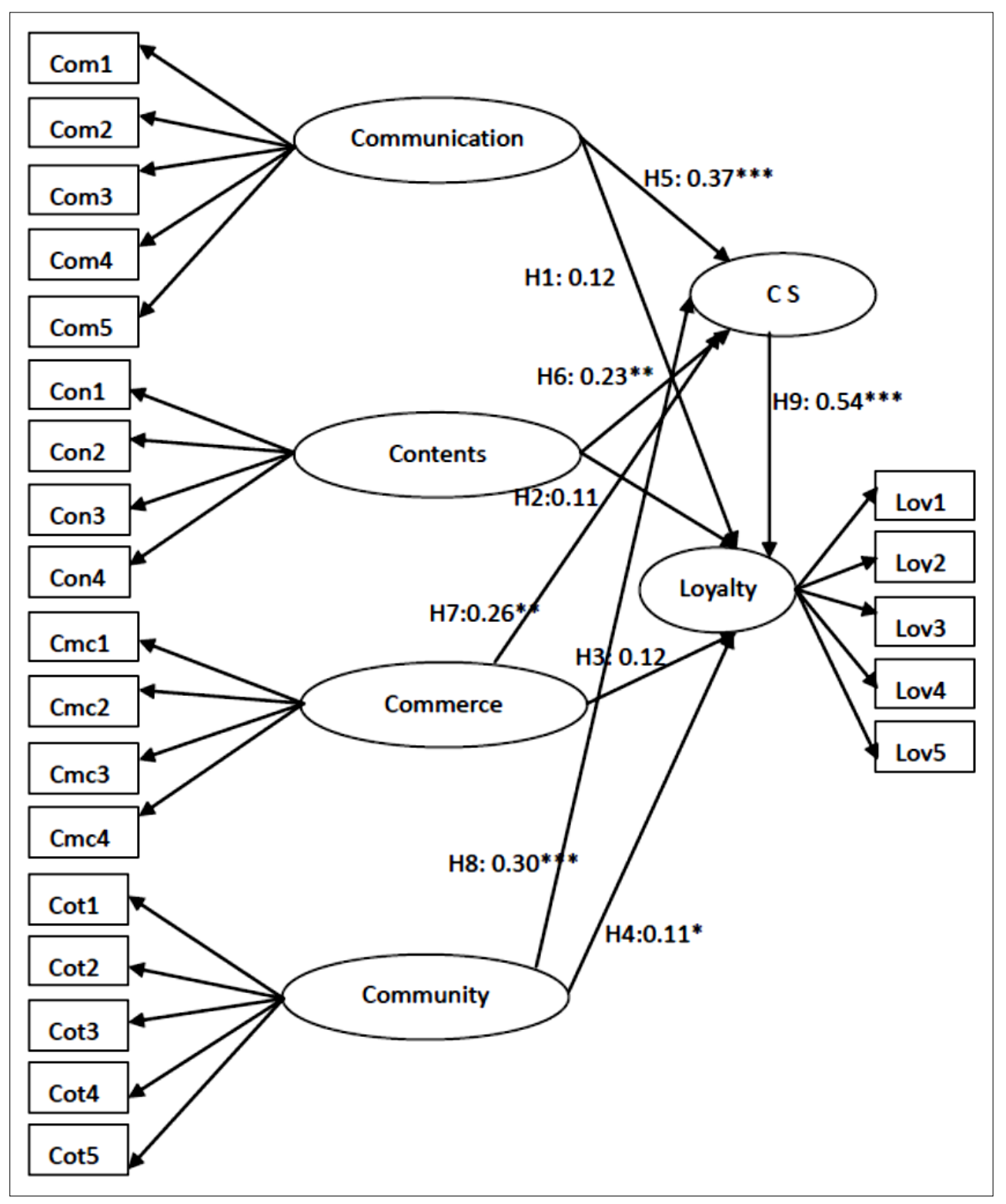

The results indicate that web marketing strategies concerning communication, content, and commerce influence customer loyalty fully and positively through customer satisfaction with online shopping. Customer satisfaction could be an important governance factor in the relationship between the web marketing mix and its sustainable performance.

If the community strategy attempts to create relationships in the final stage of the web marketing mix, the strategy also partially affects customer satisfaction. This implies that the final completion of the web marketing mix using community strategy may create customer satisfaction with governance for sustainable performance and loyalty together, while the community strategy does not exclude the role of intermediary in the creation of Chinese loyalty (Guanxi).

\section{Conclusions}

The sustainable governance of the web marketing mix is increasingly significant for the rapidly changing Chinese business environment. There is an urgent need to identify factors that contribute to 
web marketing performance. The leading global e-business companies, such as eBay, Amazon.com, Facebook, and Google could not outperform Chinese industry leaders such as Alibaba and its twin, Taobao, etc. This paper proposed web marketing mix strategies concerning the 4Cs for outstanding sustainable performance in Chinese online shopping. The study empirically tested the procedural approach to determine the governance factors contributing to customer satisfaction and Chinese loyalty (Guanxi) using the SEM. We find that the majority of web marketing mix strategies are fully mediated with customer satisfaction concerning loyalty, whereas community is partially mediated.

This paper did not examine Chinese loyalty (Guanxi) in detail. However, Chinese loyalty (Guanxi) differs from general trust or reliability because it considers relational-based responsibility as the benefactor of Chinese loyalty (Guanxi). Because of this highly responsible collaboration, creating, maintaining, and utilizing Chinese loyalty is complex. This relationship should be based on the win-win rule toward future monetary remuneration. Financial compensation provides Guanxi with governance, which is defined as the workable mechanism for sustainable performance of the collaboration network [5]. This research emphasizes the role of satisfaction concerning loyalty as the governance factor for the sustainable performance of web marketing. The majority of global e-businesses emphasize convenience and practical merits as governing factors, which results in the loss of potential customers. Therefore, entry to the Chinese web market should be based on relational management with respect to the $4 \mathrm{Cs}$ web marketing mix.

\section{Acknowledgment}

This work was supported by the National Research Foundation of Korea Grant funded by the Korean Government (NRF-2014S1A5B1011422).

\section{Author Contributions}

This research was designed, and written by the first as well as the corresponding author, and performed and analyzed the data by the coauthor.

\section{Appendix}

Table A1. The measurement items for latent variables.

\begin{tabular}{lllllllll}
\hline \multicolumn{1}{c}{ Questions } & $\begin{array}{l}\text { Strongly disagree } \rightarrow \\
\text { Strongly agree }\end{array}$ \\
\hline The questions concerning communication & 1 & 2 & 3 & 4 & 5 & 6 & 7 \\
1. No difficulty obtaining shopping information-(Com1) & 1 & 2 & 3 & 4 & 5 & 6 & 7 \\
2. No difficulty connecting with Aliwangwang customer service-(Com2) & 1 & 2 & 3 & 4 & 5 & 6 & 7 \\
3. It is easy to get a response concerning inquiries-(Com3) & 1 & 2 & 3 & 4 & 5 & 6 & 7 \\
4. Most of the Tmall(Taobao) information is useful-(Com4) & 1 & 2 & 3 & 4 & 5 & 6 & 7 \\
5. The product becomes more credible after communication-(Com5) & &
\end{tabular}


Table A1. Cont.

\begin{tabular}{|c|c|}
\hline Questions & $\begin{array}{l}\text { Strongly disagree } \rightarrow \\
\text { Strongly agree }\end{array}$ \\
\hline \multicolumn{2}{|l|}{ The questions concerning content } \\
\hline 1. Web design of Tmall is insightful-(Con1) & 12334567 \\
\hline 2. I feel comfortable e-shopping on Tmall-(Con2) & 1234567 \\
\hline 3. I feel the information in Tmall is accurate-(Con3) & 1234567 \\
\hline 4. Tmall is secure concerning private information-(Con4) & 1234567 \\
\hline \multicolumn{2}{|l|}{ The questions concerning commerce } \\
\hline $\begin{array}{l}\text { 1. The price of the same product in Tmall is cheaper than the off-line } \\
\text { shopping mall-(Cmc1) }\end{array}$ & 1234567 \\
\hline 2. There are many brand advertisements in Tmall-(Cmc2) & 1234567 \\
\hline 3. I support bonus points in Tmall-(Cmc3) & 1234567 \\
\hline 4. I appreciate e-purchase coupons in Tmall-( $\mathrm{Cmc} 4)$ & 1234567 \\
\hline \multicolumn{2}{|l|}{ The questions concerning community } \\
\hline 1. I feel like a family member of the Tmall community-(Cot1) & 12234567 \\
\hline 2. I am happy to receive communication from Tmall-(Cot2) & 1234567 \\
\hline 3. If asked questions by others, I answer them happily-(Cot3) & 1234567 \\
\hline 4. I participate in events in the Tmall community-(Cot4) & 1234567 \\
\hline 5. If I raise issues, I will certainly get a response-(Cot5) & 1234567 \\
\hline \multicolumn{2}{|l|}{ The questions concerning customer satisfaction } \\
\hline 1. I feel happy whenever I purchase in Tmall-(Sat1) & 1234567 \\
\hline 2. I'm satisfied with the service of Tmall-(Sat2) & 1234567 \\
\hline 3. I'm satisfied with the price of products in Tmall-(Sat3) & 1234567 \\
\hline 4. The shopping experience with Tmall was one of the best-(Sat4) & 1234567 \\
\hline \multicolumn{2}{|l|}{ The questions concerning customer loyalty } \\
\hline 1. I visit the Tmall homepage regularly-(Loy1) & 1234567 \\
\hline 2. When I buy products, Tmall is my first choice-(Loy2) & 1234567 \\
\hline 3. I will recommend Tmall to other people-(Loy3) & 1234567 \\
\hline $\begin{array}{l}\text { 4. Even if the price of product in Tmall is higher than others, I will still } \\
\text { choose Tmall-(Loy4) }\end{array}$ & 1234567 \\
\hline 5. I think I want to buy most items from Tmall-(Loy5) & 12345667 \\
\hline
\end{tabular}

\section{References}

1. Chinese Internet Network Information Center (CNNIC). Annual Statistics of Internet in China. Available online: http://www.199it.com/archives/187771.html and http://news.xinhuanet.com/ tech/2014-01/16/c_126015636.htm (accessed on 28 May 2014).

2. The Economist. E-commerce in China: The Alibaba phenomenon. Available online: http://www.economist.com/news/leaders/21573981-chinas-e-commerce-giant-could-generateenormous-wealthprovided-countrys-rulers-leave-it (accessed on 23 June 2014).

3. Wang, P.; Wang, H. The Implications and Suggestions of $\mathrm{C} 2 \mathrm{C}$ web Marketing in China. Available online: http://www.cnki.com.cn/Article/CJFDTotal-AHNY200620154.htm (accessed on 20 May 2006). (In Chinese) 
4. Bum, Y. The Bottlenecks of $\mathrm{C} 2 \mathrm{C}$ web Marketing in China. Available online: http://wenku.baidu.com/link?url=lmX_8yMt7Xrt-1Ni7eCQFD9rgrEz1OGW0xy0vrCez8ZXptYi4Kx_MIy69mEzFfQRQJtjs9yzGjzOC-guDhpXPSjTqMeV0oVnCpSoFUmsiS (accessed on 20 February 2009). (In Chinese)

5. Choi, Y. Global e-Business Management: Theory and Practice; Bomyoung-books Publishing Co.: Seoul, Korea, 2014; p. 54.

6. Dick, A.S.; Basu, K. Customer Loyalty: Toward an Integrated Conceptual Framework. J. Academy Market. Sci. 1994, 22, 99-113.

7. Bennettt, R.; Charnine, E.J.; Hartel, J.R. Experience as a moderator of involvement and satisfaction on brand loyalty in a business-to-business setting. J. Ind. Market. Manag. 2005, 34, 97-107.

8. Rauyruen, P. Relationship quality as a predictor of B2B customer loyalty. J. Bus. Res. 2007, 60, 21-31.

9. Chang, H.H.; Chen, S.W. The Impact of Customer Interface of Quality, Satisfaction and Switching Costs on E-loyalty: Internet Experience as a Moderator. J. Comput. Hum. Behav. 2008, 24, 2927-2944.

10. Selnes, F. An Examination of the Effect of Product Performance on Brand Reputation, Satisfaction and Loyalty. Eur. J. Market. 1993, 27, 19-35

11. Odden, L. What is Content? Learn from $40+$ Definitions. Available online: http://en.wikipedia.org/wiki/Content_(media)\#cite_note-1 (accessed on 20 February 2014).

12. Amblee, N.; Bui, T. Harnessing the Influence of Social Proof in Online Shopping: The Effect of Electronic Word of Mouth on Sales of Digital Microproducts. Int. J. Electron. Commerce 2011, 16, 91-114.

13. Lin, H.-F. Empirically testing innovation characteristics and organizational learning capabilities in e-business implementation success. Internet Res. 2008, 18, 60-78.

14. Daylian (Korean Newspaper). China socialists, Korea Capitalists? Available online: http://dailian.co.kr/news/view/253506 (accessed on 23 June 2014). (In Korean)

15. Loiacono, E.T.; Watson, R.T.; Goodhue, D.L. WEBQUAL: A measure of website quality. J. Market. Theor. Appl. 2002, 13, 432-438.

16. Kotler, P.; Armstrong, G. Principles of Marketing, 11th ed.; Pearson/Prentice Hall: Upper Saddle River, NJ, USA, 2005.

17. Hansemark, O.C.; Albinson, M. Customer Satisfaction and Retention: The Experiences of Individual with Employees. Manag. Serv. Q. 2004, 14, 40-57.

18. Oliver, R.L. Measurement and Evaluation of Satisfaction Process in Retail Settings. J. Retail. 1981, 57, 25-48.

19. Oliver, R.L. Satisfaction: A Behavioural Perspective on the Consumer, 2nd ed; M.E. Sharpe Inc.: New York, NY, USA, 2007; p. 4.

20. Chang, H.H.; Chen, S.W. The Impact of Customer Interface of Quality, Satisfaction and Switching Costs on E-loyalty: Internet Experience as a Moderator. J. Comput. Hum. Behav. 2008, 24, 2927-2944.

21. Armstrong, S.J.; Overton, T.S. Estimating non-response bias in a mail survey. J. Mark. 1977, 14, 396-402. 
22. Zeng, X.S.; Meng, X.H.; Yin, H.T.; Tam, C.Y.; Sun, L. Impact of cleaner production on business performance. J. Clean. Prod. 2010, 18, 975-983.

23. Campbell, D.T.; Fiske, D.W. Convergent and discriminant validation by the multitrait-multimethod matrix. Psychol. Bull. 1959, 56, 81-105.

24. Choi, Y.; Yu, Y. The Influence of Perceived Corporate Sustainability Practices on Employees and Organizational Performance. Sustainability 2014, 6, 348-365.

25. Bagozzi, R.P.; Yi, Y. On the evaluation of structural equation models. Acad. Mark. Sci. 1988, 16, 74-93.

26. Baron, R.M.; Kenny, D.A. The moderator-mediator variable distinction in social psychological research: Conceptual, strategic, and statistical considerations. J. Personal. Soc. Psychol. 1986, 51, 1173-1182.

27. Tepper, B.J.; Shafer, S.; Meredith, J.R.; Marsh, R. A clarification on conceptual and methodological issues related to the job characteristics model: A reply. J. Oper. Manag. 1996, 14, 369-372.

28. Chen, S.C.; Yen, D.; Hwang, M. Factors influencing the continuance intention to the usage of web 2.0: An empirical study. Comput. Hum. Behav. 2012, 28, 933-941.

(C) 2014 by the authors; licensee MDPI, Basel, Switzerland. This article is an open access article distributed under the terms and conditions of the Creative Commons Attribution license (http://creativecommons.org/licenses/by/3.0/). 